\title{
Renal Hydatid Disease. A case report.
}

\author{
R.K. Patial, D. Kapoor, H. Gupta, A. Kapoor
}

\begin{abstract}
Abstrak
Hidatid ginjal jarang ditemukan. Dilaporkan satu kasus hidatid ginjal, yang menimbulkan keluhan nyeri daerah pinggang atas dan didiagnosis dengan CT abdomen dan pemeriksaan serologik. Diberikan terapi albendazol $400 \mathrm{mg} 2$ kali sehari sebanyak 3 siklus, setiap siklus lamanya 28 hari. CT abdomen 6 bulan kemudian tidak menemukan kista lagi.
\end{abstract}

\begin{abstract}
Renal hydatid disease is uncommon even in countries where it is endemic accounting for less than $3 \%$ of all cases. We report a case of renal hydatid disease, for its rarity, presenting as dull ache in left loin and diagnosed on abdominal CT and hydatid serology. It was treated with 3 cycles of Albendazole $400 \mathrm{mg}$ twice a day, each cycle of 28 days duration. Abdominal CT done 6 months later showed disappearance of the cyst.
\end{abstract}

Keywords: Kidney, Hydatid Cyst, Albendazole

Hydatid disease is prevalent throughout the world and is endemic in Australia, Newzealand, South America, Africa and Middle East. Primary hydatid disease of kidney is rare even in countries where it is endemic and account for less than $3 \%$ of all cases. ${ }^{1}$ We report a case with review of literature of primary hydatid disease of kidney for its rarity.

\section{Case Report}

A 39 year old male, non-alcoholic, vegetarian, farmer by occupation presented in the Medical O.P.D. with a history of dull ache in the left loin for the last 30 days which was continuous, increased on walking and had no relation to meals. The pain did not interfere with his normal routine activity. On questioning, he was rearing sheep and was having a pet dog in the house. Clinical examination showed mild pallor. Abdominal examination revealed tenderness in the left lumbar region without any palpable mass or lump. Rest of the physical and systemic examination was non-contributory.

His haemogram showed $\mathrm{Hb}-9 \mathrm{~g} \%$, TLC-5600/cmm with Poly-72\%, Lympho-25\%, Mono-1\% and Eosinophil 1-2\%, Biochemical investigations includ-

I.G. Medical College, Shimla-1, India ing liver and renal functions were within normal limits. Routine and microscopic examination of urine was also normal. X-ray chest, abdomen showed no abnormality. USG abdomen did not reveal any abnormal finding. CT scan Abdomen (Fig. 1) showed a cyst 2.0 $\mathrm{X} 2.1 \mathrm{~cm}$ in size with well defined margins. Intravenous urography was normal. Serological tests for hydatid was positive by indirect haemagglutination. Amoebic serology and serology for HIV was negative.

Patient was prescribed tablet Albendazole $400 \mathrm{mg}$ twice a day for 28 days. The symptoms improved after 20 days of therapy. The therapy was repeated for two cycles of 28 days each. CT scan done after 6 months of therapy showed disappearance of the cyst.

\section{DISCUSSION}

Hydatid disease manifests commonly as liver cyst (75\%) and lung cyst (15\%), but no structure of the body, right from the brain to the fallopian tube is exempt. "Hydatid cyst is formed by implantation of Echinococcus granulosus larvae. Ultrasonography and CT scan has led to increased recognition of hydatid disease at the atypical sites. Hydatid disease of kidney are usually single and located in the cortex. Symptoms vary according to the stage of the disease. Patient may be asymptomatic or may report flank pain, haematuria, hypertension or a smooth palpable, often tender renal mass. ${ }^{3}$ The cyst may rupture and manifest as hydaturia. 
It is the only pathognomic evidence of hydatid disease of kidney. The skin test (Casoni's test) is accurate in $90 \%$ of cases. Serological tests like Indirect haemagglutination are equally sensitive. Eosinophilia is detected in $20-50 \%$ of cases. ${ }^{2} \mathrm{X}$-ray abdomen may show a soft tissue mass in the kidney are with or without calcification. Ultrasonography reveals typically a fluid filled mass lesion. CT abdomen shows a characteristic unilocular or multilocular cyst with well defined walls, readily enhancing after Intravenous contrast. $^{3}$
Therapy with Albendazole $400 \mathrm{mg}$ twice a day for 28 days and repeated for 1-8 cycles, separated by drug free interval of 2-3 weeks have been shown to be most efficacious causing reduction in the size of hydatid cyst and rarely disappearance. ${ }^{4}$

The size, number, location, and symptoms determine the surgical therapy which includes partial or total nephrectomy. ${ }^{3}$ Recurrence of the disease is possible, since there is high risk of reexposure.

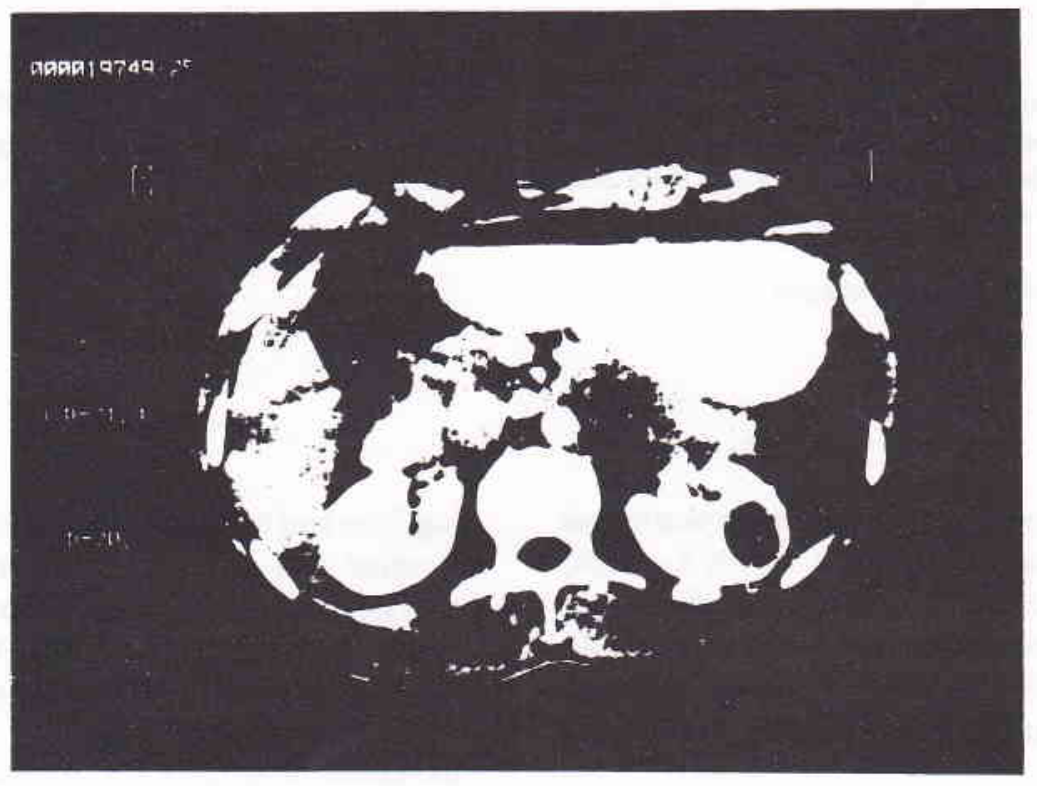

Figure 1. CT abdomen showing well defined fluid filled cyst in left kidney $2.0 \times 2.1 \mathrm{~cm}$.

\section{REFERENCES}

1. Singh R, Bhadury S, Singh SK. Primary hydatid cyst in the spleen and kidney. Preoperative diagnosis. The Indian $\mathbf{J}$ Radiol Imaging 1993;3:131-3.

2. Nabizadeh I, Morchouse HT, Freed SZ. Hydatid disease of kidney. Urology 1983;22:176-8.
3. Afsar H, Yagci F, Aybasti N, Meto S. Hydatid disease of the kidney. Br J Urology 1994;73:17-22.

4. Horton RJ. Chemotherapy of Echinococcus infection in man with Albendazole. Aust NZ J Surg 1989;59:665. 